\title{
Emerging opportunities: the internet, marketing and museums
}

\author{
Evdoxia Richani ${ }^{1}$, Georgios Papaioannou ${ }^{2}$, Christina Banou ${ }^{3}$ \\ ${ }^{1}$ BSc, MSc LIS-Museology, Dep. Archives, Library Science and Museology, Faculty of Information Science and Informatics, Ionian \\ University. Greece \\ ${ }^{2}$ Assistant Prof. Dep. Archives, Library Science and Museology, Faculty of Information Science and Informatics, Ionian University, \\ Greece \\ ${ }^{3}$ Assistant Professor, Dep. Archives, Library Science and Museology, Faculty of Information Science and Informatics, Ionian \\ University, \\ Greece
}

\begin{abstract}
The tremendous impact of applying new technologies is obvious when it comes to museums. Internet forms an integral part of museums everyday life and decision making. Websites, online communities, social media, and mobile applications comprise elements of the modern museum's digital self, which complements the real museum of permanent and temporary exhibitions, storage rooms, visitors' facilities, laboratories and, most important, museum objects. This environment inevitably affects museum marketing strategies and creates relevant opportunities.
\end{abstract}

\section{Introduction}

This paper attempts to discuss a triparted cultural relationship: museums, marketing and the Internet. Museums have served as guardians of objects and people's identities. In the last few decades museums attempt to transform into multidimensional cultural centers by listening to current cultural identities. This is achieved by thematic temporary exhibitions, educational programs and regular collaborations with different ethnic groups. Towards this end, museums have recently adopted digital technologies and the Internet. Documentation, multimedia-based exhibitions, websites, special needs applications contributed towards to the modern museum's "socially relevant objectives and basic principles...toward making a population aware of its identity, strengthening that identity, and instilling confidence in a population's potential for development."[1]. New technologies have also been used for museum educational programs.

New information technologies in the last few years have changed the way people communicate, think, read, write and act. Online communities have emerged. Social networking has provided tools for information sharing. Recommendation technologies have further encouraged user participation. Museums have used technologies that provide instant access to information in various ways. "From providing visitors with handheld devices to instantly access more information about a work of art to using cards tagged with RFID chips to automatically create a personal website based on the visitors' interests, museums are experimenting with ways these new technologies can enhance the visitor experience on site and at home." [2]. Visitors' profiles, skills and needs have therefore been affected and altered. [3] "Web 2.0 technologies enable audiences to access and interpret museum information in their own time and on their own terms and to add their personal stories and memories to this body of knowledge, liberating collections from their academic and institutional context in the traditional museum space." [4]. The evolution of digital technologies and the Internet have provided museum access across the world. "...in the past decade the role of the online/web environment has grown exponentially, offering a space free of opportunities, which represents today a benefit for the exhibition's audience and offers museums a venue for fresh improvement" [5].

In this paper we discuss museums, marketing and the internet as a triparted base for museum-related opportunities.

\section{Museum marketing and the Internet}

Museum types have been categorized in four large domains: private museums, government museums, museums of nonprofit organizations and university museums [6]. According to ICOM's estimations, there are roughly more than 55.000 museums in 202 countries around the globe [7]. Most of them were created and run

\footnotetext{
${ }^{\mathrm{a}}$ Corresponding author: evarichani@ionio.com
} 
thanks to government funding and support, but new needs and realities led to government funding shortage and the need for extra funding, and this factor boosted marketing concepts in the museum world. Marketing was not initially received well in the museum society [8], but government underfunding led to museum marketing firstly in the USA and shortly afterwards in Europe [9].

Successful management in museums nowadays requires the use of marketing. It seems this is not an option; it is a necessity. From its early appearance in the 20th century [10], different museum marketing strategies have been planned and applied depending on general and individual museum needs. A common parameter seems to be the need to attract visitors and gradually increase visitors' flow [11], as well as visitors' engagement and participation.

Towards attracting visitors, internet marketing seems to be a valuable tool. Museum websites used to have a prominent role in attracting museum audiences. Museum website have added a digital self in museum realities by presenting the museum online and receiving virtual visitors that may (or may not) become real visitors. Marty and Jones state: "Virtual museum visitors are different from those that actually visit museums onsite; there are different motivations, different reasons and different expectations from the interaction with the museum." [12].

Digitized museum objects available online can support the museum's educational character. Museum marketing and the use of Internet can serve the primary museum aim as commonly accepted: "a museum is a nonprofit, permanent institution in the service of society and its development, open to the public, which acquires, conserves, researches, communicates and exhibits the tangible and intangible heritage of humanity and its environment for the purposes of education, study and enjoyment." [13]. Museums are bound to objects, but their purpose is to disseminate knowledge and educate. "Virtual exhibits are not substitutes for exhibits in museums. They are opportunities for people who have seen the real exhibits to revisit them electronically and learn more." [14]. Students can gain much from this. "The development and maintenance of a virtual museum is an ideal way to provide a student-centered constructivist learning environments. It allows students to make choices about what they want to study and provides meaningful topics that incorporate academics and culture while providing a way to get families and the community involved in their education." [15]

Mass media presence and content industries comprise fields of museum marketing and the Internet. Modern museums, in their attempts to be an integral part of the societies they are in, have become active, have undertaken new activities and they communicate them to the public. Museums affiliate themselves with mass media by forming museum content industries. These industries create and disseminate material that can be conveyed by media. "[...] museums and other collectors of art, graphics, etc., become content producers when they produce images of their art for use by consumers." [16].
Connectedness and interaction are also enhanced. "Connectedness does not merely mean to link objects together but to give visitors the opportunity to focus on their special interests by pursuing them in an interactive dialog with the museum." [17]. Museums use the internet not only to provide access to information but also to interact with visitors by getting feedback, comments, ideas and contributions. Social media play a key role in building communities of visitors who share information and develop taste. Whether having visited the museum or not, visitors can express their attitudes and share comments and information. "People do not participate merely for the fun of it. They care about having their voice heard. Museums need to respond to visitors' participation. [...] Visitor participation, whether in the gallery or online through social media, is an important part of the museum's quest to remain relevant in society. Tools, such as the participatory aspect of social media, are strategies that allow museums to be as relevant to their audiences as possible."[18]. Visitors' view may affect museums' policies, aims, objectives, strategies and futures.

Let us not underestimate the marketing's key role: funding. Nowadays most museums are partly or completely self-financed. "In the 1990s, moreover, the policy focus increasingly shifted from merely encouraging private support to a more full-blown privatization or de-governmentalization of public cultural institutions - a trend that was particularly evident in Central and Eastern Europe [...]. [19]. Internet can be (and may already have been) a necessary factor in the museum's financial life, since it offers ways to increase museum finances. "Museums through the internet can reach global markets, which allow consumers to purchase products and services from museums throughout the world. Global marketing breaks down national boundaries, encouraging museums to interact with another across the world". [20]

\section{Internet and museums}

At the beginning, museum websites were mostly used as brochures to invite the public to visit, to promote new exhibitions and inform about collections and activities. Later on, photographs of museum artifacts started to be included in museum websites along with some information. Global communication via the World Wide Web provided museums the opportunity to contact each other fastly and in an economic way, using new means of contact, such as computer mediated conferencing (CMC), e-mail lists, discussion boards, bulletin boards and chat rooms, which were used to support many types of discursive or collaborative activities. Nowadays, social networking is used for offering and sharing information as well as for creating online communities [21].

Every museum curator, even with the smallest budget, must nowadays pursue an online representation of the museum. [22] As stated before one of the simplest presence of museums online was the "brochure museum". This type of museums usually informs people about 
visiting hours, tickets' prices and says a few words about their collection. Later on, a new museum form was introduced on the web, "the content museum". Many museums have at their collections millions of artifacts. This type of museums presents a part of the collection and invites virtual visitors to explore. "Content museums" usually display online the most special artifacts in order to intrigue people to go and see these artifacts in person. One step further is the "learning museum". At this type, "the site is didactically enhanced and linked to additional information that motivates the virtual visitor to learn more about a subject they are interested in and to revisit the site." [23].

The latest development comes in the form of virtual museums, also noted as hyper museums, digital museums, cyber museums or web museums. A virtual museum can be the World Wide Web self of traditional museums (e.g., displaying digital representations of existing collections or exhibits), or it can be created from digital content such as net art, virtual reality and digital art. "A virtual museum is a construction, a code in itself, which is encoded technically by the website developer and socially by the curator. [...] Just like in a traditional museum, curators are responsible for what is included, and what is excluded from a body of knowledge." [24]. Virtual museums offer virtual visits and virtual activities, such as virtual games for students based on CVE (collaborative virtual environments).[25].

At the communication end, museums in the last decade have moved towards incorporating the benefits of social media. "Social media indeed gives museums additional opportunities to build online communities, both on their own websites and on popular international networks like Facebook or Twitter, which potentially can extend their cultural outreach beyond national borders." [26]. Social media has revolutionized communications by providing a stable and affordable platform for ongoing dialogue that goes beyond national boundaries among countries around the world. This communication could be established by museum professionals and at the same time by simple visitors without cultural, social, political and geographical boundaries.

In the last few years museums entered the world of mobile (smart)phones, tablets, applications and services. Mobile applications for museums are rapidly increasing. "The use of mobile apps opens up new channels of communication between the cultural institution and the user, which extent to his or her personal space and go beyond the boundaries of the museum's walls." [27].

\section{Strategic marketing and museums}

During the last quarter of the $20^{\text {th }}$ century a new term was introduced to museum societies: new museology, a concept that shifted museums' centre from objects to society. These thoughts were the outcome of the post World War II shift in museum identity within the broader European society and the world [28], and introduced new ways of expressions and new roles in the relationship of museums and society [29], including an advanced educational role of museums [30]. Today museums actively contribute to social, cultural and economic life of a society [31]. Within this new role and given the funding shortages, museums seek new funds and sustainability [32]. Towards this end, museums apply marketing techniques and strategies [33].

The strategic marketing process is a very hard and worth-working process, having long term results and benefits. Marketing helps museum people to set aims and objectives, forces them to face the difficulties and exploit opportunities, helps to develop a more distinctive structure and makes good use of all different professions in a museum. Marketing is used not only to increase finance, but also to attract visitors, to penetrate into new audiences, to gain feedback from visitors so as to understand and measure needs and expectations, enriching the visitor's experience and widening the borders of the museum $[34,35,36]$.

\section{Some concluding thoughts}

"The ways in which historical, art historical, and scientific studies are changing through the use of technology are legion. The difficulty of recalling past research on a given topic is problematic and mounts with each passing year" [37].

The advantages of applying new technologies in museums are certainly many. Going online means for a museum to exploit all the given possibilities. First of all, by using the web a museum offers free access to the artifacts for everyone. This is especially important for people who are physically and/or economically disabled or live far away from the actual museum. For them it might not be possible to gain access in a specific museum and its artifacts otherwise. Secondly, by exposing virtually its artifacts, museums provide a safe way for everyone to explore these artifacts, and augment symbolic capital. Thirdly, the internet provides access to artifacts which are kept in storage rooms or are not safe to be displayed. Fourth, by using all the potentials that multimedia provide, artifacts can be virtually recomposed and re-exposed in innumerable ways. Fifth, people can work with the artifacts displayed in front of them on a computer screen in various ways, e.g. put them nest to each other and play with them. Finally, new information technologies and multimedia encourage visitors to participate and be further engaged; thus the role of the visitors is upgraded, especially if we consider the social media and the potential of creating and organizing online communities, especially with the contribution of young people [38].

On the other end, museums tend to design their digital representations in a "much prettier" way than the actual thing. As years go by, real artifacts are becoming increasingly remote for safekeeping, forcing them to appear less real and secluded. Visiting a real museum is often more exciting, because of the actual presence of other people and of activities and services there. Marketing in the world of museums can help 
towards making the most of and for visitors. Services marketing [39] of tangible and intangible museum assets $[40,41]$, real and digital, will offer museums a chance to overcome funding difficulties, set new aims and objectives, and make real and virtual visitors more satisfied.

\section{References}

1. A. Hauenchild, Claims and reality of new museology: Case studies in Canada, the United States and Mexico http://museumstudies.si.edu/claims2000.htm\#2. Elements

2. W. Witschey, Museums in transition: Emerging technologies as tools for free - choice learning, Science Museum of Virginia,p.3 (2006)

3. Giannoutsou, N. Avouris, 7th Greek Convention with International participation "The ICTs in Education », p.3 (2010)

4. J. Verboom, P. Arora, Museum 2.0: A study into the culture of expertise within the museum blogosphere, , s.e., s.1., p.8 (2015)

5. Cap Sciences and TEC-Lab, Technology and the public. Evaluation of ICT in museums no. 5, ,p.8 (2013) http://online.ibc.regione.emiliaromagna.it/I/libri/pdf/LEM5th-report-technologyand-the-public.pdf

6. G. Edson, 'Museum Management', Running a museum: a practical handbook, ICOM, France, pp. 133-146

http://icom.museum/uploads/tx_hpoindexbdd/practic al handbook.pdf

7. Frequently asked questions, ICOM (2010-2015) http://icom.museum/resources/frequently-askedquestions/

8. R. Rentschler, Museum marketing: no longer a dirty word

http://www.researchgate.net/publication/237721763

Museum_marketing_no_longer_a_dirty_word

9. V. D. Alexander, A delicate balance: Museums and the marketplace, Museum management and marketing, 400-405

http://upir.ir/934/Museum-Management.pdf

10. E. Hooper - Greenhill, Museum and communication: an introductory essay, Museum, media, message, Routledge, p. 1-12 (1995) http://samples.sainsburysebooks.co.uk/97811346407 51 sample 517927.pdf

11. A. Gilmore, R. Rentschler, Changes in museum management: a custodial or marketing emphasis, Journal of management development, vol. 21, no. 10, pp. $\quad 745-760$

(2002)

http://dro.deakin.edu.au/eserv/DU:30008525/rentschl er-changesinmuseum-post-2002.pdf

12. P. F. Marty, K. Burton Jones, Museum Informatics : people, information, and technology in museums, Taylor \& Francis Group LCC, s.1., p. 192 (2009)

13. ICOM, Museum definition, http://icom.museum/the-vision/museum-definition/
14. B. Finn, Digitising museum collections Artefacts Consortium,

http://www.artefactsconsortium.org/Publications/PD Ffiles/Vol4Pics/4.10.PicturesFinn,Digitizing 75ppiWEBF.pdf

15. Dr. G. Jones, M. Christal, The future of Virtual Museums: On-Line, Immersive, 3D Environments, Created Realities Group, p. 9 (2002) http://ww.w.createdrealities.com/pdf/Virtual Museums.pdf

16. L. Kueng, R. Picard \& R. Towse, The internet and the mass media, Sage Publications LTD, London, p.7, (2008)

17. W. Schweibenz, The "Virtual Museum": New Perspectives For Museums to Present Objects and Information Using the Internet as a Knowledge Base and Communication System, Proceedings des 6. Internationalen Symposiums für Informationswissenschaft, p.189 (1998), http://www.intelyway.com/administrator/arhivi/Vid Gajsek-MUZEJI/14 isi-98-dv-schweibenzsaarbruecken.pdf

18. Rebecca Whelan, The Use of Social Media in Museums, http://trentcentre.ca/documents/public/4157FinalRep ort.pdf

19. S. Toepler, V. Kirchberg, Museum marketing: competing in the global marketplace, pp. 160-166 (2007)

20. N. G. Kotler, P. Kotler, W. I. Kotler, Museum and marketing strategy: designing missions, building audiences, generating revenue and resources, Jossey-Bass, p.34 (2008) ${ }^{2}$

21. K. Walker, Structuring Visitor Participation, Digital Technologies and the Museum Experience: Handheld Guides and Other Media, Altamira Press, pp. 109-124 (2008) http://www.lkl.ac.uk/people/kevin/book_chapter7.pd f

22. Making the Most of the Web - a Guide for Small Museums

http://www.chr.org.uk/pdfs/webforsmallmuseums07 part1.pdf

23. W. Schweibenz, The development of Virtual museums, ICOM NEWS, ICOM, no. 3, p. 3 (2004) http://icom.museum/fileadmin/user_upload/pdf/ICO M_News/2004-3/ENG/p3_2004-3.pdf

24. D. Langlais, Cybermuseology and intangible heritage, p.75 http://www.yorku.ca/etopia/docs/conference/Langlai s.pdf

25. D. Economou, Understanding social interaction and informing the design of virtual actors in collaborative virtual environments (CVEs) for learning",Technology in service of cultural heritage, Kaleidoskopio, pp. 241-249(2008)

26. N. Grincheva, The "Starfish" of cultural diplomacy: social media in the toolbox of museums http://www.culturaldiplomacy.org/acd/content/article s/2011loam/participantpapers/the starfish_of cultural_diplomacy _ social media in the toolbox of museums.pdf 
27. M. Economou, E. Meintani, Promising beginnings? Evaluating museum mobile phone apps http://www.idc.ul.ie/techmuseums11/paper/paper8.p df

28. A. Desvallées, F. Mairesse (eds), Key Concepts of Museology, Armand Colin (2010) http://icom.museum/fileadmin/user_upload/pdf/Key Concepts_of_Museology/Museologie_Anglais_BD.p df

29. V. MacCall, C. Gray, Museums and the 'new museology': theory, practice and organisational change, Museum Management and Curatorship, vol. 29, no. 1, pp. 1-17 (2013) http://www2.warwick.ac.uk/fac/arts/theatre s/cp/staf f/gray/research/new_museology_article.pdf

30. P. Vergo, The new museology, Reaktion Books Ltd, London (1989)

31. A. Timothy, P. Crispin, Museum basics, Routledge, London (2012) https://books.google.gr/books?id=POtDB4VkZK0C $\underline{\text { \&printsec }}=$ frontcover\&redir esc $=\mathrm{y} \# \mathrm{v}=$ onepage \&q\& $\mathrm{f}=$ false

32. R. Rentschler, Museum and Performing Arts Marketing: A Climate of Change Journal of Arts Management, Law and Society, vol. 28, no 1, pp. 83-96

(1998)

http://search.proquest.com/openview/d2e2061ea4b28 f0279d987ac78e992b0/1?pq-origsite $=$ gscholar

33. N. G. Kotler., P. Kotler, W. I. Kotler, Museum Marketing and strategy: Designing Missions Building Audiences Generating Revenue and Resources, Jossey-Bass (2008)

34. K. M. Ekström., Marketing of Museums', Proceedings of the 37th Macromarketing Conference, Marketing of Museums, The Macromarketing Society, Inc., Germany, pp. 207210 http://s3.amazonaws.com/academia.edu.documents/3 0231388/macromarketing2012proceedings.pdf?AWS AccessKeyId=AKIAJ56TQJRTWSMTNPEA\&Expir $\underline{\text { es}}=1454092124 \&$ Signature $=$ DNeSpPwJARW4tU0Q 3NftDd1sBAI\%3D\&response-contentdisposition=inline $\% 3 \mathrm{~B} \% 20$ filename $\% 3$ DConstructiv ism in Advertising_Exposing_I.pdf\#page $=208$

35. R. C. Blattberg, C. J. Broderick. Marketing of Art Museums, The Economics of Art Museums, University of Chicago Press, pp. 327-346 (1991) http://www.nber.org/books/feld91-1

36. F. McLean, Marketing the museum Routledge, London. (1997)

37. M. L. Anderson, Museums of the future: The impact of technology on Museum practices, Journal of the American Academy of Arts and Sciences, pp.129-162 (1999)

http://www.columbia.edu/itc/anthropology/schildkro ut/6353/client edit/week14/anderson.pdf

38. D. Tsichritzis, S. Gibbs, Virtual museums and virtual realities, International Conference on Hypermedia \& Interactivity in Museums, Archives \& Museum Informatics, pp. 17-25 (1991) http://www.archimuse.com/publishing/hypermedia/h ypermedia.Ch3.pdf
39. A. M. Rushton, D. J. Carson, The Marketing of Services: Managing the Intangibles, European Journal of Marketing, vol. 19, Iss: 3, pp. $19-40$ (1985).

http://www.emeraldinsight.com/doi/abs/10.1108/EU M0000000004748

40. J. A. Cohen., Intangible assets: Valuation and Economic Benefit, John Wiley \& Sons Inc., New Jersey (2005)

41. O. A. Aghan. Marketing intangible heritage to museum publics: the case of folklore, ICOM MPR conference, ICOM (2006) http://network.icom.museum/fileadmin/user_upload/ minisites/mpr/papers/2006-Papers.pdf 